\title{
JOINT OPTIMIZATION OF REPLACEMENT AND SPARE ORDERING FOR CRITICAL ROTARY COMPONENT BASED ON CONDITION SIGNAL TO DATE
}

\section{WSPÓLNA OPTYMALIZACJA WYMIANY I ZAMAWIANIA CZĘŚCI ZAMIENNYCH DLA KRYTYCZNEGO KOMPONENTU OBROTOWEGO NA PODSTAWIE DOTYCHCZASOWEGO SYGNAtU STANU}

\begin{abstract}
It is widely accepted that condition-based replacement can not only make full use of components, but also decline inventory cost if the procurement of spare parts can be triggered upon accurate failure prediction. Most of the existing degradation or failure prediction models and approaches are population-based failures or suspensions, namely, to predict the failure time of a component, there are some failure or suspension histories of same type or similar components which can be used as reference. However, in practice, there exists the phenomenon in which no failure or suspension histories for some components can be used, what can be utilized is just the collected condition monitoring signals to date. In that case, failure time and probability are difficult to be estimated accurately. In this paper, a novel degradation prediction approach is introduced. Meantime, a new failure probability estimation function is developed based on component "service time" and "degradation extent" simultaneously. Then replacement and spare part ordering are jointly optimized according to the estimated failure probability. The optimization objective is to minimize long-run cost rate. Two bearing datasets are used to validate the proposed approach.
\end{abstract}

Keywords: degradation prediction, failure probability, condition-based replacement, spare part ordering.

\begin{abstract}
Powszechnie przyjmuje się, że wymiana w oparciu o stan techniczny pozwala nie tylko na petne wykorzystanie elementów sktadowych, ale także na zmniejszenie kosztów magazynowych (zwiazanych z przechowywaniem zapasów) jeśli zamawianie części zamiennych da się powiązać z trafnym prognozowaniem uszkodzeń. Większość istniejących modeli i teorii predykcji degradacji lub uszkodzeń opiera się na danych populacyjnych o uszkodzeniach lub zawieszeniu pracy co oznacza, że czas uszkodzenia komponentu przewiduje się w odniesieniu do historii uszkodzeń lub zawieszeń pracy tego samego typu lub podobnego typu elementów składowych. Jednak $w$ praktyce zdarza się, że dla niektórych komponentów nie istnieją historie uszkodzeń lub zawieszenia pracy, do których można by się odnieść; jedyne co można wykorzystać to zgromadzone dotychczas sygnaty z monitorowania stanu. W takim przypadku, trudno jest ocenić dokładnie czas i prawdopodobieństwo wystapienia uszkodzenia. W niniejszej pracy, przedstawiono nowatorskie podejście do przewidywania degradacji. Opracowano nowa funkcję szacowania prawdopodobieństwa uszkodzenia oparta na jednoczesnym wykorzystaniu "czasu pracy" oraz "stopnia degradacji" komponentu. Następnie wspólnie zoptymalizowano procesy wymiany i zamawiania części zamiennych zgodnie z szacowanym prawdopodobieństwem wystapienia uszkodzenia. Celem optymalizacji była minimalizacja długoterminowego wskaźnika kosztów . Poprawność proponowanego podejścia zweryfikowano z wykorzystaniem dwóch zbiorów danych dotyczacych łożysk.
\end{abstract}

Stowa kluczowe: prognozowanie degradacji, prawdopodobieństwo wystapienia uszkodzenia, wymiana w oparciu o stan, zamawianie części zamiennych.

\section{Introduction}

Unexpected system failures pose significant problems in power industry and most manufacturing companies. In some cases, a critical component failure can incur catastrophic events and huge economic loss. To maintain machines at high level of reliability, some companies perform time-based preventive maintenance or age-based preventive maintenance to avoid sudden failure of machines. Usually, preventive maintenance tasks includes lubrication, cleaning, inspection, adjustment, alignment and/or replacement [25]. Even though above maintenance schemes may decline the probability of sudden downtime to some extent, high maintenance cost may be generated due to frequent "over maintenance". Some companies hold lots of spare parts inventory in case the shortage of spare parts for maintenance actions. If the spares ordering is inappropriate, companies have to suffer high inventory quantity or high inventory holding cost.
A widely accepted view of decreasing unnecessary cost, including maintenance cost, inventory cost and equipment failure loss, is to perform condition-based maintenance on critical components. Recently, condition based maintenance has been studied extensively as one of the most important maintenance method. To guarantee the effectiveness and economy of maintenance, a new failure probability estimation function is established based on a novel remaining useful life prediction using condition monitoring signal to date. The estimated failure probability is the basis of replacement determination which is related to jointly optimize replacement time and spare ordering. In terms of spare ordering, spares should be ordered at right time to trade off spares shortage cost and inventory holding cost. Therefore, the reasonable decisions for replacement and spare ordering should include when to perform replacement and purchase spare parts. All the decisions are based on accurate failure prediction. The main con- 
tribution is that this method focuses on the situation in which a critical component without failure or suspension histories of same type components.

Due to the importance of RUL prediction, many scholars proposed different methods or models for various applications. Lee et al. [6] reviewed the methodologies and applications of prognostics and health management design for rotary machinery systems. Li et al. [7] analyzed products reliability using unbalanced data, in which unbalanced data means the number and time of measurements are not identical for degradation units. Roughly, the existing work can be divided into two classes, one class is the prediction models and methods are population-based, which means there are failure or suspension histories of same type components can be used. The other class is individual-based, which uses the collected individual condition monitoring signal to date. Defined by Tian et al. [15], a failure history means that a component is replaced with a new one due to its failure. A suspension history refers that a component is replaced by a new component before its failure and never used again. Wu et al. [26] optimized condition-based maintenance using prognosis information with consideration of prediction uncertainty which is estimated by the artificial neural network (ANN) lifetime prediction errors during the ANN training and testing processes. Zhang et al. [28] made the maintenance decision based on the Bayesian belief network prediction results using failure data. Lu et al [9] predicted bearing remaining useful life only using truncated histories. All the works above are mainly population-based to predict RUL.

In practice, some components cannot obtain failure or suspension histories of same type or similar components, for example, high reliability requirement and unique designed work. In this case, failure prediction is difficult, especially for an individual. Because no failure or suspension histories can be used to reflect the degradation process during whole lifecycle of components. The prediction models or methods are hard to be developed because the parameters and network constructions cannot be estimated appropriately. Works on this area are few and limited. Di Maio et al [1] proposed a relevance vector machines and exponential regression method to estimate bearing remaining useful life. The results show that the prediction result can be more accurate if more data is collected. While, at the beginning of prediction, the difference between real values and predicted values is big. Xiao et al [27] proposed a novel bearing degradation approach based on shrunken time windows and back-propagation neural network (BPNN). The prediction method uses limited amount of collected condition monitoring data for a component to date.

Maintenance is not only related to component condition, it has a strong interconnection with the availability of spare parts. Van Horenbeek et al. [16] summarized the joint optimization of maintenance and inventory from the views of inventory policy, maintenance characteristics, delays, multi-echelon networks, single-unit versus multi-unit systems, objective function and optimization techniques. Wang [19] determined preventive maintenance interval, spare order interval and order quantity simultaneously. Spare parts are ordered periodically instead on demand. Nguyen et al. [12] studied the impact of the spare parts inventory level on maintenance and replacement decisions under technological change rather than determining optimal order level/order quantity for spare parts. Panagiotidou [13] performed periodically inspection and preventive maintenance to the detected items. Meanwhile, two types of silent failures are considered when optimizing spare parts ordering and maintenance policies. Gan and Shi [3] considered replacement part order and buffer inventory when optimizing the maintenance policy for the upstream machine. System and decision process are modeled by discrete Markov method with the minimal expected cost rate control-limit policy. Zhang et al. [29] utilized the semi-Markov decision process to propose a maintenance optimization. Wang et al. [17, 18] proposed condition-based replacement and spare provisioning policies for deterioration systems.
Rausch and Liao [14] addressed a joint production and spare part inventory driven by condition based maintenance. However, these joint decision policies do not utilize the updated RUL prediction from observed information. Some other works focus on the joint optimization of periodic preventive maintenance/periodic replacement and spare inventory/ordering $[5,10,20]$.

In recent decades, the sensor technology is developed and enables to conduct system health monitoring, the condition-based or sensorbased maintenance planning and spare ordering seems more reasonable. Elwany \& Gebraeel [2] proposed a two-phase optimization for replacement and spare parts ordering. First, the replacement time is determined, then the spare ordering time is followed, accordingly. Most of the condition-based decision is using the population-based failure or suspension histories to approach the system failure. Wang et al. $[22,24]$ presented a prognostics-based spare part ordering and system replacement (PSOSR) policy. The spare part ordering time and the system replacement time is real-time determined according to the actual health condition. Recently, there is a few researches about the joint optimization of replacement and spare ordering that utilizing the online condition monitoring. Louit et al. [8] considered conditionbased monitoring and optimized the spares ordering time. Wang et al. [23] proposed a prognostic-information-based joint order-replacement policy for a non-repairable critical system in service.

Even though there are some research on the joint optimization of replacement and spare ordering, the research is still deficient. This paper is an integrated view from RUL prediction to joint optimization of replacement and spare ordering. Mainly, this paper focuses on the situation in which no failure or suspension histories can be used for a single critical component. What can be used is only the collected condition monitoring data to date. A novel approach for degradation and RUL prediction from Xiao et al [27] is introduced. Then, a new failure probability function is defined based on "service time" and "degradation extent". According to the estimated failure probability, replacement and spare ordering are optimized simultaneously with the objective of minimizing the long-run expected cost per unit time. Different from the existing research, this paper focuses on the degradation properties of individual component. The introduced RUL prediction method can predict system degradation in the early phase of lifecycle with limited amount of data. Moreover, most of the existing failure probability estimation methods use population-based failure or suspension histories, the proposed failure probability estimation function connects system "service time" with "degradation extent". Owing to failure probability, the balance among preventive replacement, failure replacement, spare part shortage cost, and inventory holding cost are traded-off in the view of individual component lifecycle horizon.

This paper is organized as follows: Section 2 states the problem briefly and describes the procedure of joint optimization, assumptions and notations. Section 3 introduces the novel prediction approach, failure probability estimation and joint optimization model of replacement and spare ordering. Section 4 presents a case study using simulation bearing dataset and real dataset from PHM 2012 competition. Final conclusions are drawn in Section 5.

\section{Procedure of joint optimization, assumptions and notations}

Condition monitoring provides an opportunity to enhance component lifecycle management including component failure prediction, maintenance planning and spares inventory. Spares inventory can be declined and optimized via the implementation of condition-based maintenance with high accuracy of component failure prediction. Hence, accurate component failure prediction is the fundamental of condition-based maintenance and spare inventory ordering/control. Among the existing work, failure prediction for components using population-based failure or suspension histories is researched a lot. 
While, the prediction work is difficult when no failure or suspension histories of same type or similar components can be used as reference. Because the whole degradation processes cannot be reflected by historical data. Moreover, the parameters of the prediction models are hard to be estimated with the limited amount of data to date. In this case, we introduced a novel method to predict an individual critical component degradation and RUL, then a new failure probability function is formulated and connected "service time" with "degradation extent". Based on the failure probability, the joint optimization of replacement and spare ordering is developed. The procedure of the proposed condition-based joint optimization of replacement and spares ordering is described in Fig. 1.

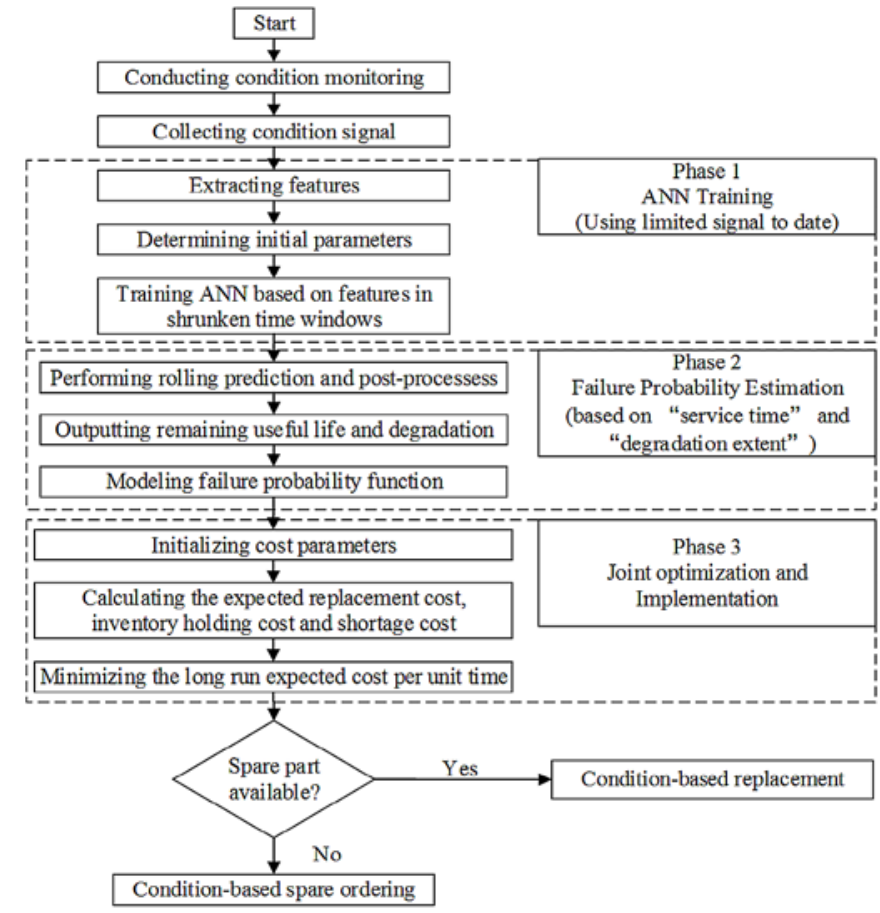

Fig. 1. Procedure of the proposed joint optimization of replacement and spares ordering

In the first phase, condition monitoring is conducted on an individual component. Condition monitoring signal is collected. Advanced feature extraction method is used to extract features which reflect degradation of the component and are prepared for training ANN. Some initial parameters are set before ANN training, such as, maximum training epoch, performance goal, initial time window, etc. Then the initial time windows are shrunken and the remained features in the shrunken time windows are used to train ANN.

In the second phase, the well trained ANN is used to perform lopfng-step ahead rolling prediction. After each prediction epoch, the predicted results are post-processed and compared with predetermined failure threshold, then the predicted RUL is outputted along with degradation.[27] According to the component "service time" and "degradation extent", failure probability is estimated.

In the third phase, the cost parameters are initialized, such as preventive replacement cost, failure replacement cost, inventory holding cost, spare shortage cost, and spare ordering cost. The failure probability function is used to estimate the expected costs. Finally, the best policy of replacement and spare ordering can be determined based on the minimizing long-run expected cost per unit time. According to the optimal policy, the availability of spare part is checked out, if the spare part is available, condition-based replacement is performed at the right time, alternatively, a spare ordering should be placed at the optimized ordering time.

In this paper, some basic assumptions and notations are listed as follows.
A1: During the condition monitoring process, sampling is periodic with equivalent sampling frequency.

A2: In general, the degradation signal shows an increasing tendency.

A3: No lead time for carrying out a preventive replacement or failure replacement, namely, replacement is performed immediately.

A4: Leading time of spare part is fixed elapsed from the moment of placing an order until order receipt.

A5: Inspection cost is not considered in this paper. We assumed the inspection cost can be neglected compared with other costs.

\section{Notation Description}

$f \quad$ Fluctuation factor

ST Start time of prediction

$w s_{0} \quad$ Initial time window size

$\mathbf{W}_{k 1}, \mathbf{W}_{k 2} \quad$ Feature matrixes in the shrunken windows

$w s_{k} \quad$ Shrunken time window size

$m_{k 1}, m_{k 2} \quad$ Mean values of $\mathbf{W}_{k 1}$ and $\mathbf{W}_{k 2}$

$r_{k} \quad$ Final increasing rate

inputn, Numbers of neurons in input layer, hidden layer and

$\begin{array}{ll}\text { hidden, } & \text { Numbers of } \\ \text { outputn } & \text { output layer }\end{array}$

$\sigma \quad$ A constant in interval $(1,10)$

$\mathbf{F}_{p} \quad$ Predicted features matrix

F Features matrix of the whole life

$f_{\text {th }} \quad$ Failure threshold

FN Normalized feature matrix

cumsum Accumulated summation

FNC Cumulative feature matrix

FP Cumulative failure probability

$F P_{t} \quad$ Cumulative failure probability at time $t$

$C_{p r} \quad$ Preventive replacement cost

$C_{f r} \quad$ Failure replacement cost

$C_{o} \quad$ Ordering cost

$C_{h} \quad$ Holding cost per unit time

$C_{s} \quad$ Shortage cost per unit time

$c_{e} \quad$ System expected cost per unit time

SC Expected shortage cost

HC Expected holding cost

$C_{e} \quad$ Total excepted cost

$t_{o} \quad$ Spare part ordering time

$t_{r} \quad$ Replacement time

L Spare part transit time

$T \quad$ Failure time

$T_{e} \quad$ Expected time until replacement

\section{Problem formulation}

\subsection{Degradation and RUL prediction for an individual com- ponent}

The introduced individual component degradation and RUL prediction is proposed by Xiao et al. [27]. The method uses limited 
amount of recorded condition monitoring data to date. According to the proposed prediction approach, the procedure of their method is summarized in Fig. 2 as follows.

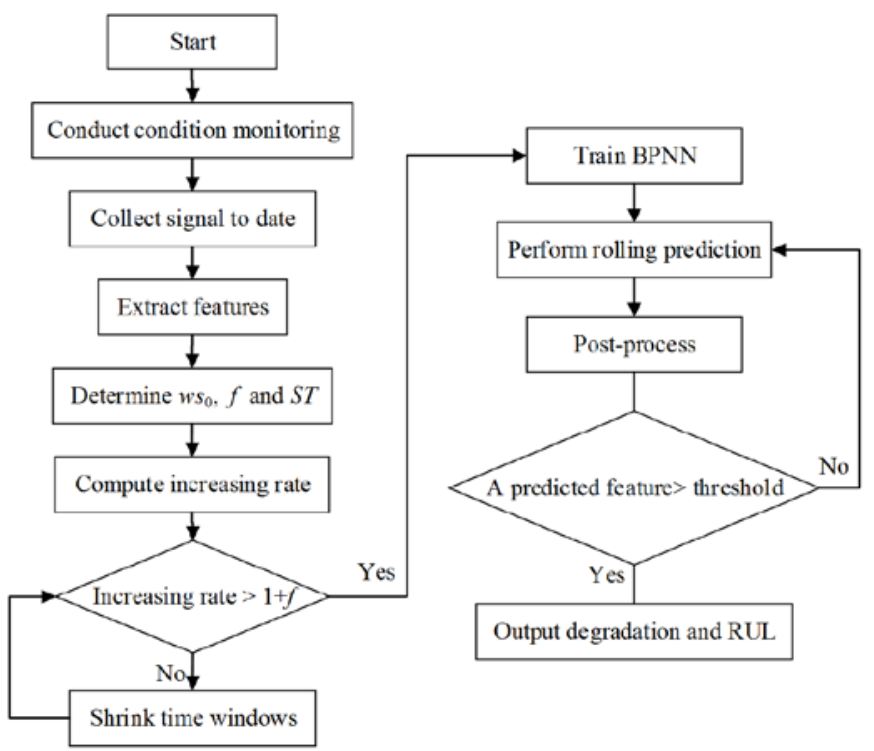

Fig. 2. Procedure of the proposed degradation and RUL prediction approach from Xiao et al.[27].

The extracted features from condition monitoring data to date are prepared for training BPNN. Before training BPNN, an initial time window size $\left(w s_{0}\right)$ is given, mean values of the features in the initial time windows are calculated. The ratio of two mean values in two adjacent time windows is defined as increasing rate. Then increasing rate is compared with fluctuation factor which is set in the interval of $(0,0.1)$. If the increasing rate is greater than $(1+f)$, features in the current time windows are used to train BPNN, otherwise, the time windows are shrunken step by step, then increasing rate is recalculated according to the features in the shrunken time windows. Shrinking is terminated until the increasing rate is greater than $(1+f)$. Fig. 3 shows the comparison of time windows before and after the shrunken. The feature matrixes in the shrunken time windows, mean values and increasing rate are calculated by Eq. (1)-Eq. (3).

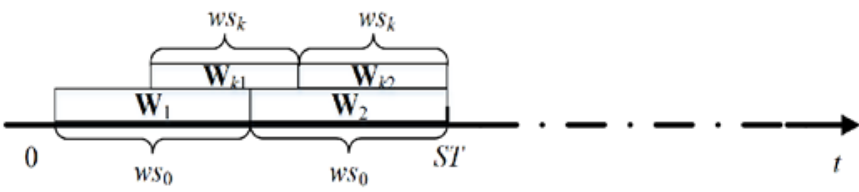

Fig. 3. Comparison of time window before and after shrunken

$$
\begin{gathered}
\mathbf{W}_{k 1}=\left[\mathbf{F}_{S T-2 w s_{k}+1} ; \mathbf{F}_{S T-2 w s_{k}+2} ; \cdots ; \mathbf{F}_{S T-w s_{k}}\right] \\
\mathbf{W}_{k 2}=\left[\mathbf{F}_{S T-w s_{k}+1} ; \mathbf{F}_{S T-w s_{k}+2} ; \cdots ; \mathbf{F}_{S T}\right] \\
m_{k 1}=\frac{\sum_{n=1}^{w s_{k}} \mathbf{F}_{S T-2 w s_{k}+n}}{w s_{k}} \quad m_{k 2}=\frac{\sum_{n=1}^{w s_{k}} \mathbf{F}_{S T-w s_{k}+n}}{w s_{k}} \\
r_{k}=\frac{m_{k 2}}{m_{k 1}}
\end{gathered}
$$

Where, $S T$ is the start time of prediction, $w s_{0}$ is initial time window size, $\mathrm{W}_{k 1}$ and $\mathrm{W}_{k 2}$ are feature matrixes in the $k^{\text {th }}$ shrunken windows respectively, $w s_{k}$ is the shrunken time window size. Mean values of
$\mathrm{W}_{k 1}$ and $\mathrm{W}_{k 2}$ are $m_{k 1}$ and $m_{k 2}$ respectively, and $r_{k}$ is the final increasing rate.

Features matrixes $\mathrm{W}_{k 1}$ and $\mathrm{W}_{k 2}$ in the final shrunken time windows are regarded as inputs and outputs for training BPNN respectively. The number of neurons in input layer and output layer depends on the features matrix dimension. The revised empirical formula for determining the number of neurons for hidden layer is as follows:

$$
\text { hidden }=\lceil\sqrt{\text { inputn }+ \text { outputn }}\rceil+\sigma
$$

Where hidden, inputn and outputn are the numbers of neurons in hidden layer, input layer and output layer, respectively. $\sigma$ is a constant in interval $(1,10)$.

After determining the training samples and BPNN construction, BPNN is trained. Multi-step ahead rolling prediction is performed. In each prediction epoch, there are $w s_{k}$ tuples of feature predicted, the rolling prediction is performed as Eq. (5). The outputs in each prediction epoch should be post-processed using Eq. (6) and Eq. (7):

$$
\left\{\begin{array}{l}
{\left[\mathbf{F}_{S T-2 w s_{k}+1} ; \cdots ; \mathbf{F}_{S T-w s_{k}}\right] \rightarrow\left[\mathbf{F}_{S T-w s_{k}+1} ; \cdots ; \mathbf{F}_{S T}\right]} \\
{\left[\mathbf{F}_{S T-w s_{k}+1} ; \cdots ; \mathbf{F}_{S T}\right] \rightarrow\left[\mathbf{F}_{S T+1} ; \cdots ; \mathbf{F}_{S T+w s_{k}}\right]} \\
\vdots \\
{\left[\mathbf{F}_{m+1} ; \cdots ; \mathbf{F}_{m+w s_{k}}\right] \rightarrow\left[\mathbf{F}_{m+w s_{k}+1} ; \cdots ; \mathbf{F}_{m+2 w s_{k}}\right]}
\end{array}\right.
$$

$$
\begin{aligned}
& \text { if } \mathbf{N F}_{t}<\mathbf{N F}_{t-w s_{k}} \text { then } \mathbf{N F}_{t}=\mathbf{N F}_{t-w s_{k}} \\
& \text { if } \mathbf{N F}_{t}>(1+f) \times \mathbf{N F}_{t-w s_{k}} \quad \text { then } \mathbf{N F}_{t}=(1+f) \times \mathbf{N F}_{t-w s_{k}} \\
& \text { if } \mathbf{P F}_{t} \times r_{k} \geq f t \quad \text { then } R U L=t-S T \\
& \text { if } \mathbf{P F}_{t} \times r_{k}<f t \quad \text { then rolling prediction }
\end{aligned}
$$

\subsection{Novel component failure probability estimation method}

Component failure probability is the basis when balancing the joint optimization of replacement and spare ordering. Since no failure or suspension histories of same type or similar components can be used as population-based reference, a new failure probability estimation function is proposed using the predicted features based on "service time" and "degradation extent". The "degradation extent" of the features can be formulated as Eq. (8):

$$
\mathbf{F N}=\frac{\mathbf{F}}{f_{t h}}=\frac{\left[\mathbf{F}_{1} ; \mathbf{F}_{2} ; \cdots ; \mathbf{F}_{S T} ; \mathbf{F}_{p}\right]}{f_{t h}}
$$

Where, $\mathrm{F}$ is features matrix of the whole life. $\mathrm{F}_{\mathrm{p}}$ is predicted feature matrix. $f_{t h}$ is failure threshold. $\mathrm{FN}$ is normalized feature matrix.

Eq. (8) describes the relationship between features at current time and predetermined failure threshold. If a feature is closed to failure threshold, the failure probability is higher. In terms of "service time", it is based on a widely accepted assumption which is that the failure probability is higher if a component serves for longer time. Hence, the failure probability is formulated as follows:

$$
\mathbf{F N C}=\operatorname{cumsum}(\mathbf{F N})
$$




$$
\mathbf{F P}=\frac{\mathbf{F N C}}{\operatorname{sum}(\mathbf{F N})}
$$

Where, cumsum represents accumulated summation. FNC is cumulative feature matrix. FP is cumulative failure probability which is a monotonic increasing function in interval of $(0,1]$. A component is subject to random failure with the failure probability $F P_{t}$ at time $t$.

\subsection{Joint optimization of condition-based replacement and spare ordering}

In this paper, the objective is to determine the optimal replacement and spare part ordering time along with the component being monitored. Two replacement policies are considered. One is preventive replacement which refers to performing replacement before the component failed. The other is failure replacement which refers to performing replacement after the component failed. The two replacement policies generate different maintenance costs which are $C_{p r}$ and $C_{f r}$, respectively. In general, failure replacement can cause higher cost than preventive replacement, that is $C_{f r}>C_{p r}$. Before performing replacement, the availability of spares in stock should be checked out. If there are available spare parts before the required time, inventory holding cost is incurred with the cost per unit time $C_{h}$, alternatively, shortage cost with cost per unit time $C_{s}$ is generated if the spare part is unavailable. If a spare part is needed while unavailable, an order is placed with ordering $\operatorname{cost} C_{o}$.

Considering all the possible scenarios, the relationship among spare part ordering, replacement and component failure is shown in Fig.4. Where, $t_{o}$ is spare part ordering time, $t_{r}$ is replacement time, $L$ is leading time of spare part. $T$ is failure time of the component. Theoretically, it is possible for a component to be replaced at any time since $S T$ until its failure. If a spare ordering is placed, a new spare can be available after a fixed leading time $L$. During the period, the system has to suffer a potential shortage of spare part with a shortage cost which is formulated as Eq. (11). However, if the spare is arrived before the required time, the system has to suffer the inventory holding cost which is as Eq. (12).

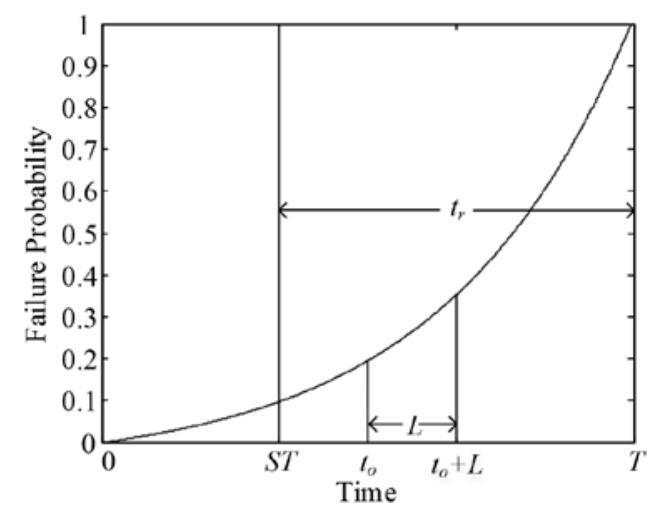

Fig. 4. The relationship among spare part ordering, replacement and component failure

$$
\begin{gathered}
S C=C_{S} \times \int_{t=0}^{L} F P_{t_{0}+t} d t \\
H C=C_{h} \times \int_{t=0}^{t_{r}-t_{0}-L}\left(1-F P_{t_{0}+L+t}\right) d t
\end{gathered}
$$

Where, $S C$ and $H C$ are the expected shortage cost and the expected holding cost, respectively. $t$ is integration time step.
Therefore, the total excepted cost $C_{e}$ is as Eq. (13). The expected long-run time until replacement is denoted as $T_{e}$ can be deduced as Eq. (14). The expected long-run total cost rate, $c_{e}$, can be calculated by Eq. (15):

$$
\begin{gathered}
C_{e}=C_{o}+S H+H C+C_{p r} \times\left(1-F P_{t}\right)+C_{f r} \times F P_{t} \\
T_{e}=\int_{t=0}^{L} F P_{t_{0}+t} d t+\int_{t=0}^{t r}\left(1-F P_{t}\right) d t \\
c_{e}=\frac{C_{e}}{T_{e}}
\end{gathered}
$$

The objective of this paper is to determine the best replacement time and spare ordering time by minimizing the expected long-run total cost per unit time. It can be formulated as follows:

$$
\begin{array}{cc}
\min & c_{e}(\mathrm{t}) \\
\text { s.t. } & S T \leq t \leq T \\
& F P_{t} \leq 1
\end{array}
$$

\section{Case study}

In this section, we validate the proposed model using two bearing datasets, one is simulated degradation dataset, and the other is a realworld condition monitoring dataset from PHM 2012 competition.

\subsection{Simulated bearing dataset}

The run-to-failure (RTF) simulation experiment is based on the work of McFadden and Smith [11] and Wang and Kootsookos [21], the more details can be found in Ref [28]. The simulated signal is extracted by wavelet packet analysis. The wavelet base is "db4", decomposition level is three. Energy of wavelet packet coefficients is the feature vector. The first dimension of the features is selected as the key element, if the feature at a time point in the first dimension exceeds $1400 \mathrm{~Hz}$, the simulated bearing is regarded as failed. The degradation path of the key element of the simulated bearing is shown as Fig. 5.

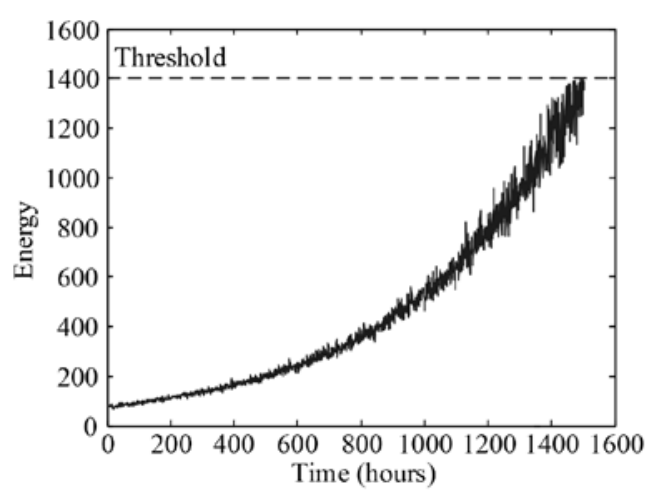

Fig. 5. Degradation path of the key element of the simulated bearing

Since $1400 \mathrm{~Hz}$ is set as failure threshold, the lifetime of simulated bearing is 1502 time units, here the time unit is hour. Due to feature extraction method, there are eight dimensions in the feature matrixes. Accordingly, there are eight neurons in input layer and output layer in BPNN, respectively. There is one hidden layer with ten neurons. The maximal iteration epoch for BPNN training is 1000 , error goal is $1 \mathrm{e}-10$. The initial time window size is 100 , fluctuation factor is 0.02 . 

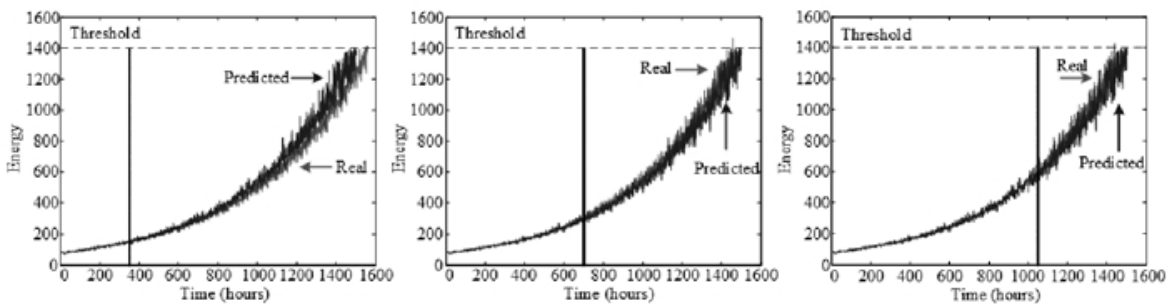

Fig. 6. Comparison of predicted and real degradation at different time points

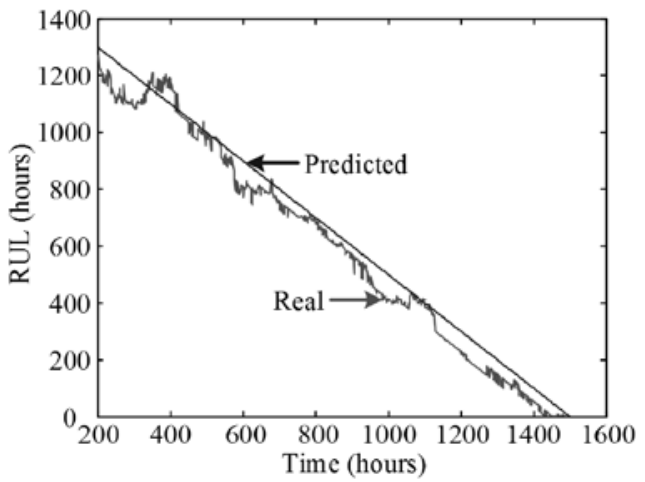

Fig. 7. Predicted RULs since $S T=200$

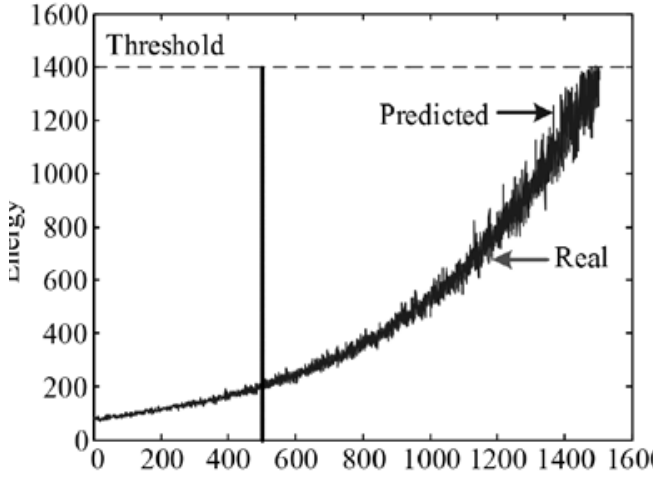

Fig. 8. Comparison of predicted degradation and real degradation at $S T=500$

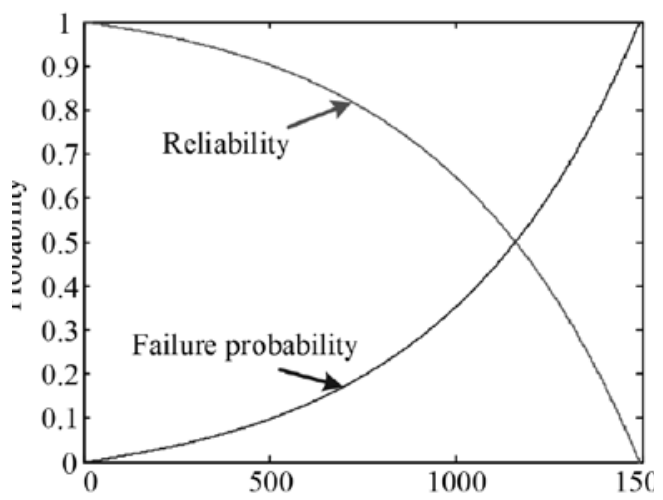

Fig. 9. Failure probability and reliability change over time

The predicted degradation and RULs at three different time points are illustrated in Fig. 6 and Table 1. Predicted RULs since $S T=200$ time units are shown in Fig. 7 compared with real values.

Taking $S T=500$ as an example, the comparison of predicted degradation and real values is descripted in Fig. 8, the corresponding failure probability and reliability change over time are shown in Fig. 9.
The following hypothetical data is used when optimizing replacement and spare ordering jointly, $L=4$ time units, $C_{p r}=\$ 200$, $C_{f r}=\$ 1000, C_{h}=\$ 1 /$ unit time, $C_{s}=\$ 500 /$ unit time, $C_{o}=\$ 300$. Using the above proposed method, the optimal spare ordering time is at 891 hours, the replacement time is at 900 hours, the long-run expected cost rate is 0.0066 , and the expected total cost is $\$ 1945$, accordingly. The expected cost rate change over the predicted lifecycle is illustrated in Fig. 10.

Table 1. Comparison of predicted and real RULs at different time points

$\begin{array}{cccc}\text { ST } & \text { Real RUL } & \text { Predicted RUL } & \begin{array}{c}\text { Predicted e } \\ (\%)\end{array} \\ 350 & 1152 & 1207 & -3.66 \\ 700 & 802 & 758 & 2.93 \\ 1050 & 452 & 388 & 4.26\end{array}$

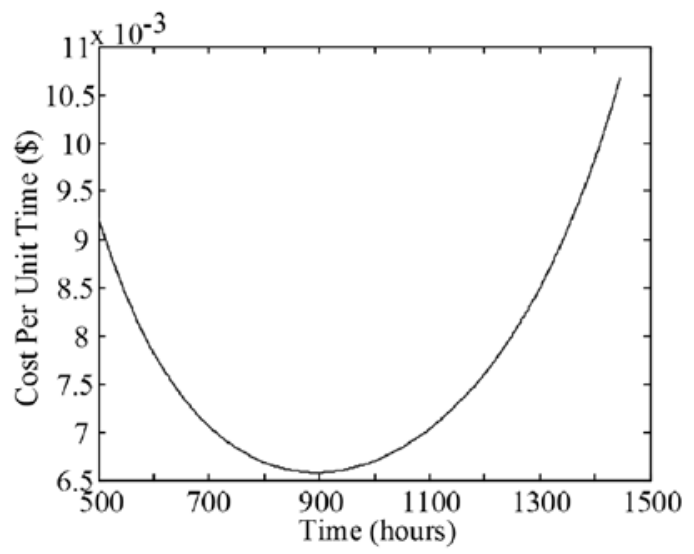

Fig. 10. Expected cost rate change over the predicted lifecycle

\subsection{PHM Competition bearing dataset}

PHM Competition bearing data is from IEEE Challenge 2012, it is real-field experimental data. Inspection was performed very 10 seconds and lasted for 0.1 second. Sampling frequency of vibration signal was $25.6 \mathrm{KHz}$, more detailed data information can be obtained from the website [4]. Shock Pulse Method (SPM) is used to extract degradation feature. The first bearing among PHM-2012 Competition

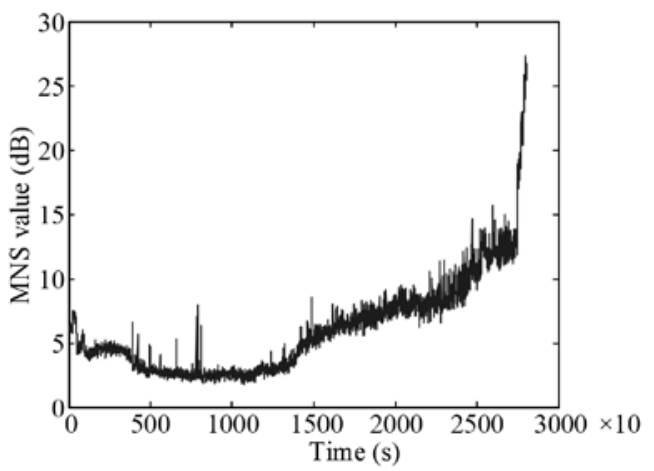

Fig. 11. MNS values of Bearing 1 from PHM-2012 Competition

bearings is used to validate the proposed method. The maximum normalized shock (MNS) value of Bearing 1 is depicted in Fig. 11. 

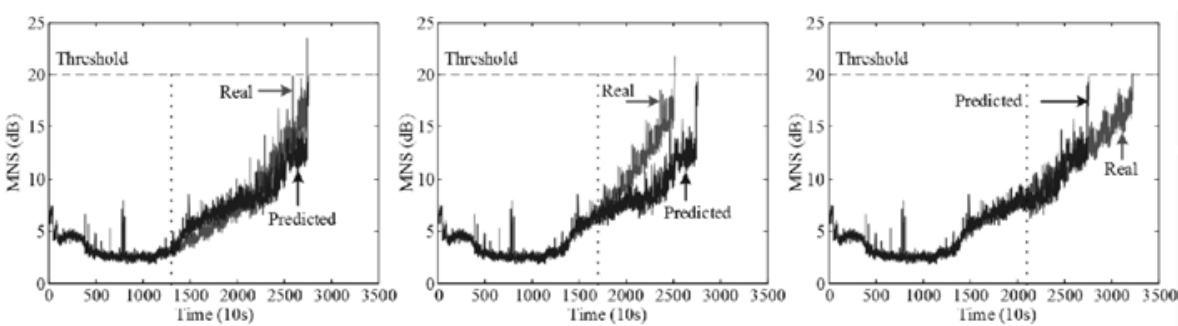

Taking $S T=1300$ as an example, the estimated failure probability and reliability change over time is shown in Fig. 14. The hypothetical cost parameters are as followed, $L=5$ time units, $C_{p r}=\$ 250, C_{f r}=\$ 1000, C_{h}=\$ 1 /$ unit time, $C_{s}=\$ 1200 /$ unit time, $C_{o}=\$ 500$. The optimal spare ordering time is at 1894 time units, the best replacement time is at 1911 time units, the long-run expected cost rate is 0.0068 , and the expected total cost is $\$ 8512.9$. The expected cost rate change over the predicted lifecycle is shown in Fig. 15.

Table 2. Comparison of predicted and real remaining useful life at different time points

$\begin{array}{cccc}\text { ST } & \text { Real RUL } & \text { Predicted RUL } & \begin{array}{c}\text { Predicted error } \\ (\%)\end{array} \\ 1300 & 1465 & 1443 & 1.25 \\ 1700 & 1065 & 817 & 14.5 \\ 2100 & 665 & 1119 & -25.72\end{array}$

From Fig. 11, MNS increases after $1000 \times 10$ s, therefore, features before $1000 \times 10$ s are not considered when training ANN and predicting RUL. The failure threshold of Bearing 1 is set $20 \mathrm{~dB}$. Hence, the bearing lifetime is $1765 \times 10$ s. The essential parameters for degradation prediction and cost rate estimation are listed as followed. The number of neurons in input layer and output layer is one, there is one hidden layer with six neurons. The initial time window is 150 , fluctuation factor is 0.05 . The predicted degradation and RULs at three

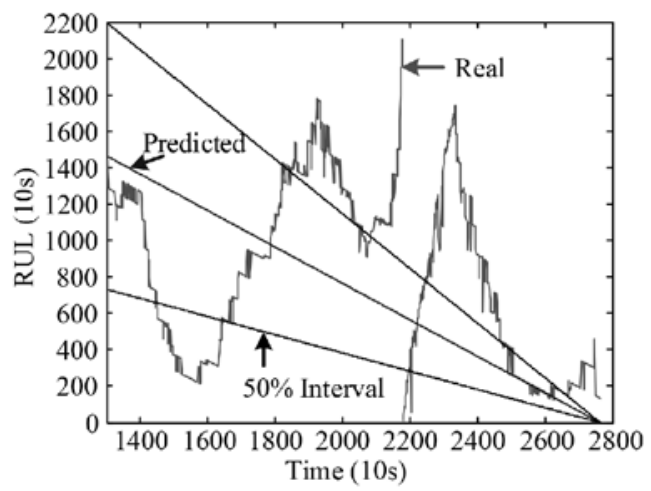

Fig. 13. RUL prediction results since $S T=1300$

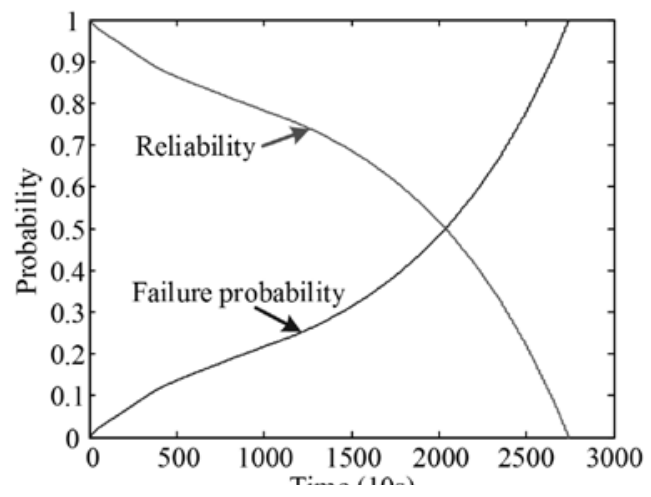

Fig. 14. Failure probability and reliability change over time

different time points are illustrated in Fig. 12 and the prediction performance is listed in Table 2. RUL prediction results since $S T=1300$ time units compared with real RULs are shown in Fig. 13.

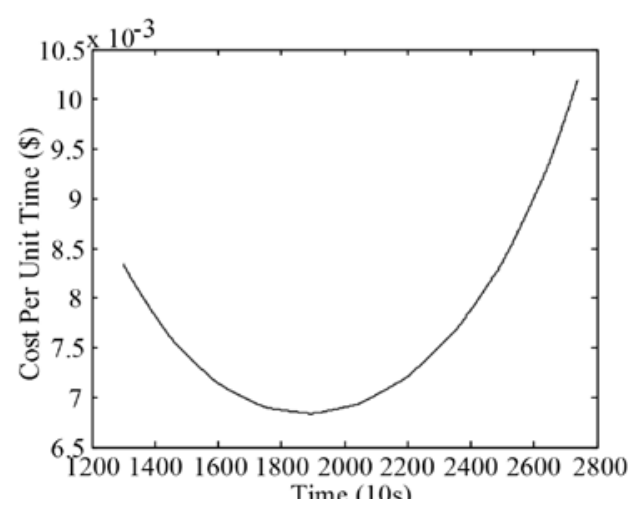

Fig. 15. Expected cost rate change over the predicted lifecycle

\subsection{Comparative parameters tuning and discussion}

For comparison, the method from Elwany \& Gebraeel [2] is used to calculate the best replacement time and spare ordering time. For the simulated bearing, the optimal replacement time is at 1049 time units, the optimal spare ordering time is at 1037 time units along with the expected long-run cost rate is 0.0068 . The total cost is $\$ 2653.7$. For the PHM-2012 competition bearing data, the best replacement time is 2189 time units, the best spare ordering time is 2164 time units, and the corresponding long-run cost rate is 0.0071 .

(1) Comparison of cost rate and replacement time

In Elwany \& Gebraeel [2] work, the best replacement time is determined according to the long-run average cost rate which is defined as followed:

$$
C_{r}=\frac{c_{p} \bar{F}\left(t_{r}\right)+c_{f} F\left(t_{r}\right)}{\int_{0}^{t r} \bar{F}(t) d t}
$$

Where, $C_{r}$ is the expected long-run replacement cost, cp is the planned replacement cost, $\mathrm{cf}$ is the failure replacement cost. $F(t)$ is the cumulative density function of component's failure time. $\bar{F}(t)=1-F(t)$.

For more comparison, different inventory holding costs and shortage costs are tuned for comparative discussion. For the simulated bearing, inventory holding cost is varied from $\$ 0.2$ /unit time to $\$ 1$ / unit time, the interval is $\$ 0.2$ /unit time, at the same time, shortage cost varies from $\$ 50 /$ unit time to $\$ 250 /$ unit time with the interval of $\$ 50 /$ unit time. For PHM 2012 Competition bearing, the inventory holding cost is changed from $\$ 0.2 /$ unit time to $\$ 2 /$ unit time with the interval of $\$ 0.2 /$ unit time, the shortage cost varies from $\$ 50 /$ unit time to $\$ 1200$ / unit time with the interval of $\$ 50 /$ unit time. Comparing our proposed joint optimization method in this paper with the method in Elwany \& Gebraeel [2], the respective cost rates and best replacement times are shown in Fig. 16 and Fig. 17. 


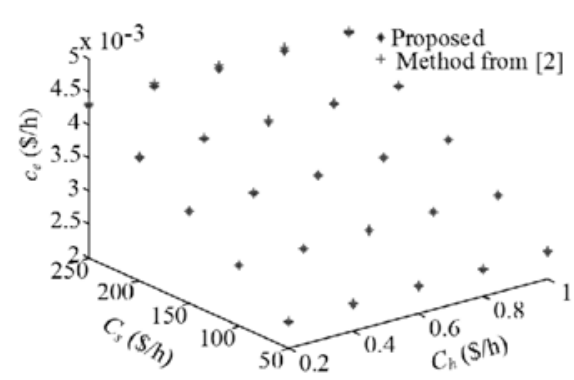

Simulated bearing

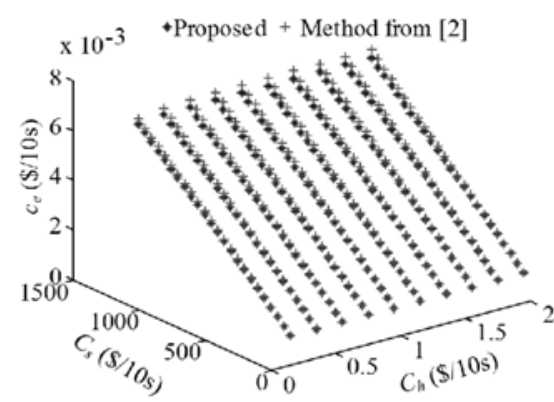

PHM 2012 Competition bearing

Fig. 16. Comparison of cost rates with different inventory holding costs and shortage costs

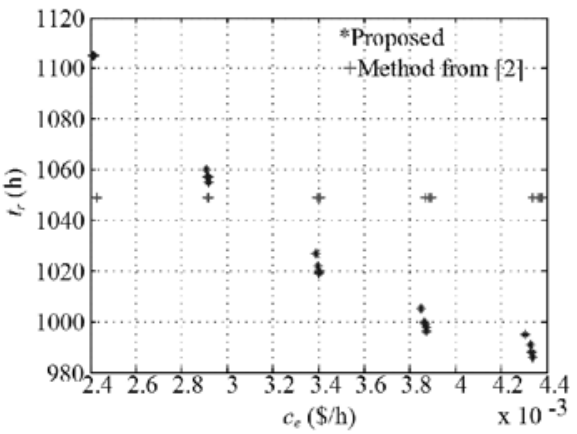

Simulated bearing

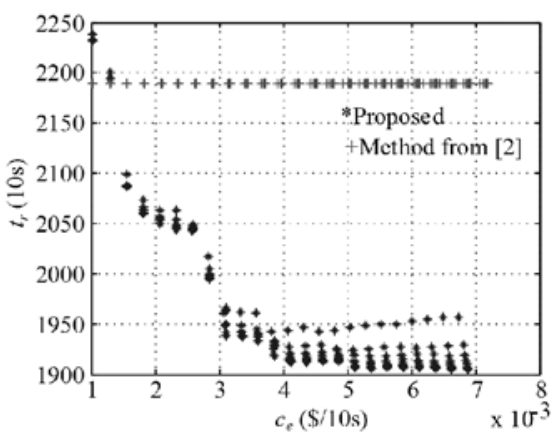

PIIM 2012 Competition bearing

timal replacement time and spare ordering time from Elwany \& Gebraeel's work:

$$
\begin{aligned}
& x=t_{r}{ }^{*}-t_{o}{ }^{*}-L \\
& y=t_{r^{*}}-t_{o^{*}}-L
\end{aligned}
$$

Therefore, $x$ is the inventory time for our proposed method, $y$ is the inventory time for the method from [2]. Accordingly, the difference of $x$ and $y$ is the inventory time comparison. For the all sample data (which is same for the comparison of cost rates and replacement times. i.e., for PHM 2012 Competition bearing data, the inventory holding cost is changed from $\$ 0.2 /$ unit time to $\$ 2 /$ unit time with the interval of $\$ 0.2$ / unit time, the shortage cost varies from $\$ 50 /$ unit time to $\$ 1200$ /unit time with the interval of $\$ 50$ / unit time.), the inventory time comparison is shown in Fig. 18.

From Fig. 18, in Elwany \& Gebraeel's method [2], the inventory time is generally greater than our proposed method. In other words, their method scarifies inventory time to guarantee the component long service with higher cost rate.

Overall, their method can be regarded as two phases. The first phase is to determine the replacement which just concerns failure replacement cost and preventive replacement cost. The second phase is to determine the best spare order placing time according to the best replacement time. Their method may be less effective when inventory turnover ratio, inventory time and inventory quantity are critical concerns. While, in

From Fig. 16, the comparison of cost rates, the cost rates from our proposed method are less than the ones from Elwany \& Gebraeel's work [2]. Move to Fig. 17, the replacement time from Elwany \& Gebraeel's work [2] is a constant. The replacement time from Elwany \& Gebraeel's work [2] does not vary along with the spare holding cost and shortage cost. From Eq. (17), the replacement time is just impacted on the balance of planned replacement cost and failure replacement cost. After determining the best replacement time, the spare ordering time is calculated accordingly. Thus is different from our proposed method. In our proposed method, inventory holding cost and shortage cost can impact on the replacement time.

\section{(2) Comparison of inventory time}

Eq. (18) is defined to compare the inventory time for the two different methods. Where $t_{r}{ }^{*}$ and $t_{o}{ }^{*}$ are the optimal replacement time and spare ordering time from our proposed method, $t_{r^{*}}$ and $t_{o^{*}}$ are the op-

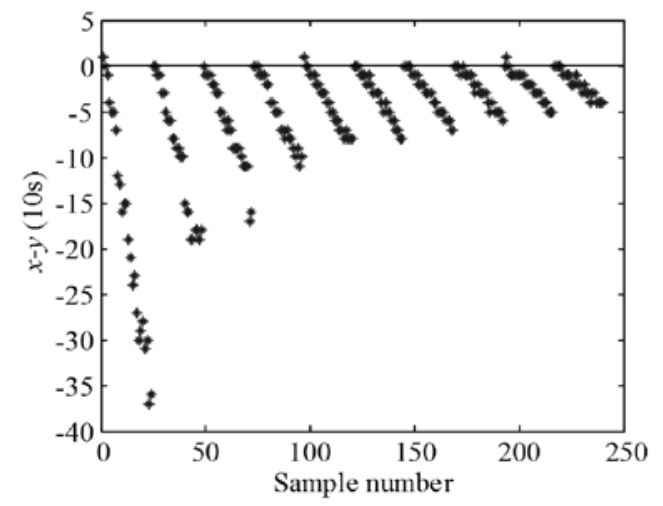

Fig. 18 Comparison of $(x-y)$ with different inventory holding costs and shortage costs for PHM 2012 Competition bearing our proposed method, the replacement time and spare ordering are optimized jointly with lower cost rates.

\section{Conclusions and prospects}

This work focuses on the optimization of replacement and spare ordering for one individual critical rotary component. For the component, there are no failure or suspension histories of same type or similar components as references when predicting its failure time and degradation. To solve the prediction problem, a novel approach is introduced. Then a new failure probability estimation function is developed based on "service time" and "degradation extent". The difference between the developed method and the existing method, the failure probability is more focused on individual property, rather than the population-based character. Replacement and spare ordering time are determined simultaneously according to minimizing the expected long-run cost rate which is related to planned replacement cost, failure replacement cost, inventory holding cost, shortage cost and spare ordering cost. A simulated degradation bearing dataset and a real-world condition monitoring bearing dataset from PHM Competition 2012 are used to validate the proposed method. The degradation and RUL prediction performance is illustrated by comparing with the real values. The proposed approach is discussed by tuning the parameters of inventory holding cost and shortage cost. The results show that our method has lower long-run cost rate and less inventory time. It can be more effective when the inventory time, inventory turnover ratio and inventory quantity are critical concerns.

This proposed method can benefit to determining optimal replacement and spare ordering time for single component. Future research will focus on multi-component system optimization of replacement and spare ordering time with variable leading time. 


\section{Acknowledgment}

The authors would like to thank great support from Key Project supported by National Science Foundation of China (51035008), as well as the National Science\& Technology Major Project, China (No. 2016ZX04004-005).

\section{References}

1. Di Maio F, Tsui KL, Zio E. Combining Relevance Vector Machines and exponential regression for bearing residual life estimation. Mechanical Systems and Signal Processing 2012; 31: 405-427. http://dx.doi.org/10.1016/j.ymssp.2012.03.011.

2. Elwany AH, Gebraeel NZ. Sensor-driven prognostic models for equipment replacement and spare parts inventory. IIE Transactions 2008; 40(7): 629-639. http://dx.doi.org/10.1080/07408170701730818.

3. Gan S, Shi J. Maintenance optimization for a production system with intermediate buffer and replacement part order considered. Ekspolatacja i Niezawodnosc - Maintenance and Reliability 2014; 16(1): 140-149.

4. IEEE PHM 2012 Data Challenge. http://www.femto-st.fr/en/Research-departments/AS2M/Research-groups/PHM /IEEE-PHM-2012-Datachallenge.php.

5. Jiang Y, Chen M, Zhou D. Joint optimization of preventive maintenance and inventory policies for multi-unit systems subject to deteriorating spare part inventory. Journal of Manufacturing Systems 2015; 35: 191-205. http://dx.doi.org/10.1016/j.jmsy.2015.01.002.

6. Lee J, Wu F, Zhao W, Ghaffari M, Liao L, Siegel D. Prognostics and health management design for rotary machinery systems-Reviews, methodology and applications. Mechanical Systems and Signal Processing 2014; 42(1-2): 314-334. http://dx.doi.org/10.1016/j. ymssp.2013.06.004.

7. Li J, Zhang Y, Wang Z, Fu H, Xiao L. Reliability analysis of the products subject to competing failure processes with unbalanced data. Ekspolatacja i Niezawodnosc - Maintenance and Reliability 2016; 18(1): 98-109. http://dx.doi.org/10.17531/ein.2016.1.13.

8. Louit D, Pascual R, Banjevic D, Jardine AKS. Condition-based spares ordering for critical components. Mechanical Systems and Signal Processing 2011; 25(5): 1837-1848. http://dx.doi.org/10.1016/j.ymssp.2011.01.004.

9. Lu C, Tao L, Fan H. An intelligent approach to machine component health prognostics by utilizing only truncated histories. Mechanical Systems and Signal Processing 2014; 42(1-2): 300-313. http://dx.doi.org/10.1016/j.ymssp.2013.08.025.

10. Lynch P, Adendorff K, Yadavalli VSS, Adetunji O. Optimal spares and preventive maintenance frequencies for constrained industrial systems. Computers \& Industrial Engineering 2013; 65(3): 378-387. http://dx.doi.org/10.1016/j.cie.2013.03.005.

11. McFadden PD, Smith JD. Model for the vibration produced by a single point defect in a rolling element bearing. Journal of Sound and Vibration 1984; 96(1): 69-82. http://dx.doi.org/10.1016/0022-460X(84)90595-9.

12. Nguyen TPK, Yeung TG, Castanier B. Optimal maintenance and replacement decisions under technological change with consideration of spare parts inventories. International Journal of Production Economics 2013; 143(2): 472-477. http://dx.doi.org/10.1016/j.ijpe.2012.12.003.

13. Panagiotidou S. Joint optimization of spare parts ordering and maintenance policies for multiple identical items subject to silent failures. European Journal of Operational Research 2014; 235(1): 300-314. http://dx.doi.org/10.1016/j.ejor.2013.10.065.

14. Rausch M, Liao H. Joint Production and Spare Part Inventory Control Strategy Driven by Condition Based Maintenance. IEEE Transactions on Reliability 2013; 59(3): 507-516. http://dx.doi.org/10.1109/TR.2010.2055917.

15. Tian Z, Wong L, Safaei N. A neural network approach for remaining useful life prediction utilizing both failure and suspension histories. Mechanical Systems and Signal Processing 2010; 24(5): 1542-1555. http://dx.doi.org/10.1016/j.ymssp.2009.11.005.

16. Van Horenbeek A, Buré J, Cattrysse D, Pintelon L, Vansteenwegen P. Joint maintenance and inventory optimization systems: A review. International Journal of Production Economics 2013; 143(2): 499-508. http://dx.doi.org/10.1016/j.ijpe.2012.04.001.

17. Wang L, Chu J, Mao W. A condition-based order-replacement policy for a single-unit system. Applied Mathematical Modelling $2008 ; 32$ (11): 2274-2289. http://dx.doi.org/10.1016/j.apm.2007.07.016.

18. Wang L, Chu J, Mao W. A condition-based replacement and spare provisioning policy for deterioration systems with uncertain deterioration to failure. European Journal of Operational Research 2009; 194(1): 184-205. http://dx.doi.org/10.1016/j.ejor.2007.12.012.

19. Wang W. A stochastic model for joint spare parts inventory and planned maintenance optimisation. European Journal of Operational Research 2012; 216(1): 127-139. http://dx.doi.org/10.1016/j.ejor.2011.07.031.

20. Wang Y, Zhao J, Cheng Z, Yang Z. Integrated decision on spare parts ordering and equipment maintenance under condition based maintenance strategy. Ekspolatacja i Niezawodnosc - Maintenance and Reliability 2015; 17(4): 591-599. http://dx.doi.org/10.17531/ein.2015.4.15.

21. Wang YF, Kootsookos PJ. Modeling of low shaft speed bearing faults for condition monitoring. Mechanical Systems and Signal Processing 1998; 12(3): 415-426. http://dx.doi.org/10.1006/mssp.1997.0149.

22. Wang Z, Hu C, Wang W, Kong X, Zhang W. A prognostics-based spare part ordering and system replacement policy for a deteriorating system subjected to a random lead time. International Journal of Production Research 2014; 53(15): 4511-4527. http://dx.doi. org/10.1080/00207543.2014.988892.

23. Wang Z, Wang W, Hu C, Si X, Zhang Wei. A Prognostic-Information-Based Order-Replacement Policy for a Non-Repairable Critical System in Service. IEEE Transactions on Reliability 2015; 62(2): 721-735. http://dx.doi.org/10.1109/TR.2014.2371016.

24. Wang Z, Wang Z, Hu C, Liu X. An Integrated Decision Model for Critical Component Spare Parts Ordering and Condition-based Replacement with Prognostic Information. CHEMICAL ENGINEERING TRANSACTIONS 2013; 33: 1063-1068. http://dx.doi.org/10.3303/ CET1333178.

25. Wong CS, Chan FTS, Chung SH. A joint production scheduling approach considering multiple resources and preventive maintenance tasks. International Journal of Production Research 2013; 51(3): 883-896. http://dx.doi.org/10.1080/00207543.2012.677070.

26. Wu B, Tian Z, Chen M. Condition-based Maintenance Optimization Using Neural Network-based Health Condition Prediction. Quality and Reliability Engineering International 2013; 29(8): 1151-1163. http://dx.doi.org/10.1002/qre.1466.

27. Xiao L, Chen X, Zhang X, Liu M. A novel approach for bearing remaining useful life estimation under neither failure nor suspension histories condition. Journal of Intelligent Manufacturing 2015. http://dx.doi.org/ 10.1007/s10845-015-1077-x. 
28. Zhang X, Kang J, Jin T. Degradation Modeling and Maintenance Decisions Based on Bayesian Belief Networks. IEEE Transactions on Reliability 2014; 63(2): 620-633. http://dx.doi.org/10.1109/TR.2014.2315956.

29. Zhang Z, Zhou Y, Sun Y, Ma L. Condition-based mainteannce optimization without a predetermined strategy structure for a two-component series system. Ekspolatacja i Niezawodnosc - Maintenance and Reliability 2012; (2): 120-129. http://dx.doi. org/10.1007/978-1-4419-0820-9.

\section{Xiaohui CHEN}

\section{Dawei XU}

\section{Lei XIAO}

The State Key Lab of Mechanical Transmission

Chongqing University

Chongqing 400030, China

Emails: chenxiaohui@cqu.edu.cn, DavidXu1036@163.com, leixiao211@163.com 